\title{
Causes of different goiter rates with the same iodine deficiency among the pastoral and agricultural populations of Tibet: A geographical comparison
}

\section{Jing Xu}

Chinese Center for Disease Control and Prevention National Institute for Nutrition and Health

Shichuan Liu

Hangzhou Center for Disease Control and Prevention

\section{Wei Ma}

Chinese Center for Disease Control and Prevention National Institute for Nutrition and Health

\section{Xiuwei Li}

Chinese Center for Disease Control and Prevention National Institute for Nutrition and Health

\section{Min Guo}

Institute of Endemic Diseases

\section{Xiaoxiao Cao}

Chinese Center for Disease Control and Prevention National Institute for Nutrition and Health

\section{Yunyou Gu}

Chinese Center for Disease Control and Prevention National Institute for Nutrition and Health

\section{Haiyan Wang}

Chinese Center for Disease Control and Prevention National Institute for Nutrition and Health

\section{Jianqiang Wang}

Chinese Center for Disease Control and Prevention National Institute for Nutrition and Health

\section{Ying Zhang}

Chinese Center for Disease Control and Prevention National Institute for Nutrition and Health

\section{Guangxiu Zhuang}

Chinese Center for Disease Control and Prevention National Institute for Nutrition and Health Liejun Liu ( $\square$ liuliejun@icdc.cn )

Chinese Center for Disease Control and Prevention National Institute for Nutrition and Health https://orcid.org/0000-0001-5147-7675

\section{Research}

Keywords: iodine, thyroid hormone, thyroid goiter, iodine deficiency, Tibet 
Posted Date: November 11th, 2021

DOI: https://doi.org/10.21203/rs.3.rs-1059907/v1

License: (9) This work is licensed under a Creative Commons Attribution 4.0 International License. Read Full License

Version of Record: A version of this preprint was published at Thyroid Research on March 19th, 2022. See the published version at https://doi.org/10.1186/s13044-022-00122-8. 


\section{Abstract \\ Background}

The residents of both the agricultural and pastoral areas of Tibet share the same iodine deficiency and iodine nutrition, but the rate of thyroid goiter was significantly higher in the agricultural areas than in the pastoral areas. This project sought to determine why the populations in the iodine-deficient pastoral areas show a lower rate of thyroid goiter.

\section{Methods}

Food frequency questionnaires (FFQs) and $24 \mathrm{~h}$ history recalls were adopted to investigate the dietary patterns of the residents of the agricultural and pastoral areas. Meat and milk samples were collected to measure their inorganic iodine, total iodine and thyroid hormone contents using ICP-MS, As ${ }^{\text {III-Ce }}{ }^{4+}$ catalytic spectrophotometry and the Siemens' chemiluminescence method, respectively. The intake of protein, and the microelements, selenium and iron, was calculated according to their content in the food.

\section{Results}

The per capita daily intake of meat, dairy, and cereal in the pastoral areas was 116.7, 216.7, and $433.3 \mathrm{~g}$, respectively, which are significantly higher than those in the agricultural areas $(50.0,72.2$, and $375.0 \mathrm{~g}$, respectively) $(p<0.05)$. The content of thyroid hormone in dried beef and milk in the pastoral areas was 62.6 and $13.5 \mu \mathrm{g} / \mathrm{kg}$, respectively, which was significantly higher than those in the agricultural areas (25.1 and $4.1 \mu \mathrm{g} / \mathrm{kg}$, respectively) $(\mathrm{p}<0.05)$. The daily intake of thyroid hormone, protein and microelements, selenium and iron from foods by the residents of the pastoral areas were $10.5 \mu \mathrm{g}, 99.6 \mathrm{~g}, 30.0 \mu \mathrm{g}$ and $15.8 \mathrm{mg}$ respectively, which was significantly higher than those in the agricultural areas $(1.79 \mu \mathrm{g}, 56.5 \mathrm{~g}$, $23.8 \mu \mathrm{g}$ and $13.2 \mathrm{mg}$, respectively) $(\mathrm{p}<0.05)$.

\section{Conclusions}

The significantly high intake of the food-borne thyroid hormone by the residents of the pastoral area could be the main reason the residents in the pastoral areas show a lower rate of thyroid goiter than those in the agricultural area. Moreover, the relatively high intake of protein and trace elements, selenium and iron by residents in the pastoral area could be another important factor for reducing the goiter rates.

\section{Introduction}

lodine deficiency may cause thyroid goiter, cretinism, and developmental disorders in the embryonic brain, all of which are collectively referred to as iodine deficiency disorders (IDD) [1]. Normally, IDD prevalence is closely correlated with the level of iodine deficiency in the environment. However, a strange phenomenon 
is occurring in Tibet, China, where the residents of both the agricultural and pastoral areas of Tibet share the same iodine deficiency, but the IDD prevalence between these populations is significantly different. Prior to 1995, when China had not implemented the universal salt iodization (USI) policy, the median urinary iodine concentration (UIC) of children in these areas was $40-50 \mu \mathrm{g} / \mathrm{L}$, which is a moderate iodine deficiency, according to the WHO classification standards for IDD [1]. Moreover, the residents in the agricultural areas of Tibet had a significantly higher rate of thyroid goiter $(40-52 \%)$ than those in the pastoral areas $(0 \%)$. Cretinism was also prevalent in the agricultural areas $(2-13 \%)$ but was not observed in the pastoral areas (0\%) [2-4]. After the complete implementation of the USI policy, in 1996 [5], iodized salts became widely available in agricultural areas, and the iodine levels in farming residents were fundamentally improved. However, there are a multitude of arid salt lakes in the pastoral areas of Tibet; therefore, natural table salt is free and can be easily acquired by the local herdsmen. Thus, the use of iodized salt among families in the pastoral areas and the iodine levels in these residents have not been improved. Despite this, the thyroid goiter rate in the pastoral areas was still lower than that in the agricultural areas, where residents had an adequate iodine intake (UIC $>100 \mu \mathrm{g} / \mathrm{L}$ ), after the USI policy implementation. Based on China's IDD monitoring data from 1985 [4], 2002 [6], 2011 [7], and a study by Dudan et al. in 2009 [8], the median UIC and thyroid goiter rates of children in the pastoral and agricultural areas before and after USI are shown in Table 1. Our previous study, from 2010, found that the protein intake of pastoral residents was significantly higher than that of agricultural residents, which may be an important reason for the low prevalence of goiter in the pastoral areas $[9,10]$. However, a high intake of protein alone is not sufficient to account for the reduced rate of thyroid goiter among the residents of the pastoral areas during severe iodine deficiency.

Table 1

\begin{tabular}{|c|c|c|c|c|c|c|}
\hline \multirow[t]{2}{*}{$N=100$} & \multicolumn{3}{|c|}{ Selenium intake $(\mu \mathrm{g})$} & \multicolumn{3}{|c|}{ Iron intake (mg) } \\
\hline & Median & Interquartile & Range & Median & Interquartile & Range \\
\hline $\begin{array}{l}\text { Pastoral } \\
\text { residents }\end{array}$ & 30.0 & 10.3 & $7.0 \sim 77.4$ & 15.8 & 5.8 & 7.2 37.1 \\
\hline $\begin{array}{l}\text { Agricultural } \\
\text { residents }\end{array}$ & 23.8 & 10.3 & $6.9 \sim 58.8$ & 13.2 & 6.4 & $4.5 \sim 32.2$ \\
\hline $\mathrm{p}$ & 0.000 & & & 0.001 & & \\
\hline
\end{tabular}

This project sought to determine the main reason for the lower rate of thyroid goiter in the populations of iodine-deficient pastoral areas and to determine whether USI should be carried out in these areas of Tibet.

\section{Materials And Methods}




\section{Field survey and sampling}

Naqu county and Chanang county were selected from the pastoral and agricultural areas, respectively, for the field survey. The residents in Naqu county primarily depend on livestock farming for living, and the residents in Chanang county primarily live from crop farming, and their lifestyle and food structure have remained unchanged for years. Both counties are self-sufficient in terms of economy and lifestyle. The geographical and climatic environments of the two counties are described in Table 2 [11].

Table 2 Geographical and climatic environment of the pastoral Naqu county and the agricultural Chanang county

\begin{tabular}{|llllll|}
\hline & Population & Area & Altitude & $\begin{array}{l}\text { Annual mean } \\
\text { temperature } \\
\left(\mathrm{km}^{2}\right)\end{array}$ & $\begin{array}{l}\text { Annual mean precipitation } \\
(\mathrm{m})\end{array}$ \\
\hline Naqu & 90,000 & 16,195 & 4,450 & -2.2 & 400 \\
\hline Chanang & 83,000 & 2,163 & 3,620 & 8.2 & 420 \\
\hline
\end{tabular}

The sample size was determined using the formula: $n=t_{0}{ }^{2}(1-p) p / d^{2}$, which is usually adopted to estimate the minimum sample size for cluster sampling or simple random sampling [12]. We considered the average goiter rate $(11 \%)$ of Tibetan children in 2005 as the probability (p), 1.96 as the t-critical value $\left(t_{\square}, \nabla=0.05\right)$, and $10 \%$ as the allowable sampling error $(d)$. Therefore, the sample size for each area should be 38 participants, at least $\left[n=1.96^{2}(1-0.11) 0.11 / 0.1^{2}=37.6\right]$.

Two towns each in the pastoral Naqu county and the agricultural Chanang county were selected as the investigation sites for the dietary survey. The selected towns met the following requirements: the populations should be relatively concentrated (more than 2,000 habitants per town), have low mobility, a similar economic level, and stable living habits. One hundred households from each area were randomly sampled, according to the local household registration, and one adult aged 18-55 years was selected from each family to participate in the dietary interview. In total, there were 200 participants, with an approximately equal number of men and women.

Food frequency questionnaires (FFQs) and the $24 \mathrm{~h}$ history recall were adopted to assess the dietary habits of the residents over the current and the previous year [13-15], with emphasis on meat and dairy consumption. Based on the dietary habits of Tibetan people, questions were asked about the intake of meat (yak beef, dried yak beef, cattle beef, dried cattle beef, mutton, pork, and chicken), dairy (cow milk, sheep milk, butter, and yogurt), cereals (barley, wheat, and rice), potatoes, vegetables (Chinese cabbage, green pepper, tomato, cauliflower, eggplant, lettuce, radish, mushroom, pumpkin, carrot, and cucumber), and eggs. The response options were defined as follows: "never/rarely," "1-5 times per six months," "1-3 
times per month," " 1 time per week," "2-4 times per week," "5- 6 times per week," " 1 time per day," and "2+ times per day." Subsequently, the $24 \mathrm{~h}$ history recall ( $24 \mathrm{~h}$ recall) was conducted for three consecutive days to collect the dietary data. The seasonal food intake, such as lamb in the winter and autumn, was calculated according to the annual consumption. The daily food intake was estimated using a food map developed by Nanjing Medical University, China [16].

The survey group consisted of eight well-trained surveyors and one experienced epidemiologist. The unified FFQ and $24 \mathrm{~h}$ recall questionnaires were used to conduct the household surveys, which were carried out one by one in agricultural areas first, and then in the pastoral areas. The investigators participated together in the first five household surveys for each area, and then conducted separate investigations.

Dried beef, milk, mutton, and pork were sampled and stored in an ice box, and then transported to the laboratory to measure the iodine and thyroid hormone levels.

\section{Method For Measuring The Thyroxine Levels In Milk}

The milk samples were centrifuged at 3,000 rpm $(r=16 \mathrm{~cm})$ for $10 \mathrm{~min}$, and the intermediate layer was used to measure the thyroxine $\left(T_{4}\right)$ content using the chemiluminescence method. The analysis was performed using a Siemens Adivia Centaur system and the corresponding kits. The recovery, intra- and inter-assay variation coefficients of this method were $89.2-91.6 \%, 3.96 \%$, and $5.83 \%(n=6)$, respectively [17].

\section{Method For Measuring The Thyroxine Levels In Meat}

First, the thyroxine in beef jerky was determined using the method recommended by the American Thyroid Association (ATA), in which thyroxine was extracted using methanol: chloroform (1:2) and its level was determined using radioimmunoassay (RIA) [18]. However, the results exhibited poor repeatability. The intra-assay variation coefficient ranged from $9.3-25 \%$ among the six random samples. It is possible that the protein denaturation of beef jerky makes the protein-bound thyroxine difficult to extract completely. Therefore, the method of measuring the organic iodine content in dried beef was subsequently adopted to determine the levels of thyroxine. The iodine level in dried beef primarily comes from the blood and comprises both organic and inorganic iodine, and $90 \%$ of organic iodine is thyroid hormone [19-22]. Therefore, the total iodine and inorganic iodine levels were measured in dried beef, and their differential values were considered as the levels of organic iodine. There are two types of thyroid hormones, $T_{3}$ and $T_{4}$, with the latter being more prevalent. Therefore, the $T_{4}$ levels are used to indicate the levels of thyroid hormone in dried beef and can be calculated based on the organic iodine $\left(\mathrm{I}_{0}\right)$ content, according to the following formula (1):

$\mathrm{T}_{4}(\mu \mathrm{g} / \mathrm{kg})=\mathrm{I}_{\mathrm{o}} /(4 \times 127) \times 777 \times 90 \%(1)$ 
Where:

4: one $\mathrm{T}_{4}$ molecule contains 4 iodine atoms;

127: iodine relative atomic weight;

777: $\mathrm{T}_{4}$ relative molecular weight;

$90 \%: 90 \%$ of organic iodine is thyroid hormone in the tissues.

To extract the inorganic iodine from dried beef, a $0.4 \mathrm{~g}$ sample was placed in a $5 \mathrm{~mL}$ centrifuge tube, to which $3 \mathrm{~mL}$ of deionized water and two stainless steel or ceramic grinding beads with a diameter of 2 $\mathrm{mm}$ were added. Next, a pipe cover was installed, and the apparatus was placed into a vertical vibrating ball grinder and ground for $120 \mathrm{~s}$ at a frequency of $65 \mathrm{~Hz}$. The centrifuge tube and its contents were then centrifuged for $5 \mathrm{~min}$ at 4,000 rpm. The supernatant was removed, the process was repeated three times, and the supernatants were pooled at the end. Deionized water was added to the supernatant to reach a final volume of $10 \mathrm{~mL}$. Next, $1.0 \mathrm{~mL}$ of $20 \%$ (w/w) trichloroacetic acid solution was added to the supernatants for precipitation of the protein, and the samples were placed into a constant-temperature water bath at $37^{\circ} \mathrm{C}$ for $30 \mathrm{~min}$, followed by centrifugation at 3,500 rpm for $10 \mathrm{~min}$. The thyroid hormone combined with protein and the dissociative thyroid hormone (heavier than water and insoluble in water) settled at the bottom of the tube, separate from the inorganic iodine. Then, $4.0 \mathrm{~mL}$ of the supernatant was carefully extracted and filtered with a 5 - $\mu \mathrm{m}$ syringe aqueous-phase filter membrane to measure the inorganic iodine content.

The extracted inorganic iodine was measured using ICP-MS [23]. The recovery rate was used to evaluate the effects of the extraction of inorganic iodine from the samples. A total of $1 \mathrm{~mL}$ of an iodine standard solution was added to $0.4 \mathrm{~g}$ of dried beef paste to reach an iodine content of $50 \mu \mathrm{g} / \mathrm{L}$ in the supernatants in the end. The recovery was calculated using the following formula:

Recovery \% = (inorganic iodine after standard iodine was added - inorganic iodine in the sample)/(standard iodine added) $\times 100 \%$

The recovery and intra-assay variation coefficients (cv\%) of the method for extracting and measuring the inorganic iodine level in dried beef are shown in Table 3 . The average recovery was $93.8 \pm 2.3 \%$ with a range of $89.7-96.8 \%$, and the intra-assay variation coefficients ranged from $2.4-2.9 \%$. 
Table 3

\begin{tabular}{|c|c|c|c|c|c|}
\hline & Population & $\begin{array}{l}\text { Area } \\
\left(\mathrm{km}^{2}\right)\end{array}$ & $\begin{array}{l}\text { Altitude } \\
\text { (m) }\end{array}$ & $\begin{array}{l}\text { Annual mean } \\
\text { temperature } \\
\left({ }^{\circ} \mathrm{C}\right)\end{array}$ & $\begin{array}{l}\text { Annual mean precipitation } \\
(\mathrm{mm})\end{array}$ \\
\hline Naqu & 90,000 & 16,195 & 4,450 & -2.2 & 400 \\
\hline Chanang & 83,000 & 2,163 & 3,620 & 8.2 & 420 \\
\hline
\end{tabular}

The total iodine levels in dried beef was measured using $\mathrm{As}^{\mathrm{III}}-\mathrm{Ce}^{4+}$ catalytic spectrophotometry and dry ash sampling, and the detection limit of this method was $6 \mu \mathrm{g} / \mathrm{kg}$ for a $0.5 \mathrm{~g}$ sample [24]. The reference material 8418 (wheat gluten, NIST of USA) with iodine content of $60 \pm 13 \mu \mathrm{g} / \mathrm{kg}$ was used to control the quality of the test. The ICP-MS method is not suitable for the determination of total iodine in dried beef because of the high inorganic salt content of samples after ashing.

\section{Data Input And Statistical Analysis}

The collected data were sorted and summarized. Excel software was used to establish a database and the statistical analyses were performed using SPSS20.0. The D test (R. B. D' Agostino) was used as a normality test to determine the type of distribution of the quantitative data. For skewed distribution data, the median values were adopted to describe the centralized trend and indicate the mean levels. The interquartile range was used to determine the degree of dispersion. The Wilcoxon signed-rank test was adopted to determine the significance of the differences between two groups of samples, and a value of $p<0.05$ was accepted as statistically significant. For the normal distribution data, the mean values and standard deviations were adopted to describe the mean levels and the degree of dispersion. The statistical t-test was adopted for significance assessment, and a value of $p<0.05$ was accepted as statistically significant.

\section{Results}

\section{Participants}

The number of male and female participants was approximately the same, and the age structure was not significantly different between the two areas, as shown in Table 4. 


\begin{tabular}{|c|c|c|c|c|}
\hline $\begin{array}{l}n= \\
6\end{array}$ & $\begin{array}{l}\text { Inorganic iodine in the } \\
\text { sample solution }(\mu \mathrm{g} / \mathrm{L})\end{array}$ & $\begin{array}{l}\text { Standard iodine } \\
\text { added }(\mu \mathrm{g} / \mathrm{L})\end{array}$ & $\begin{array}{l}\text { Inorganic iodine after standard } \\
\text { iodine was added }(\mu \mathrm{g} / \mathrm{L})\end{array}$ & $\begin{array}{l}\text { Recovery } \\
\text { rate (\%) }\end{array}$ \\
\hline 1 & 52.1 & 50.0 & 100.0 & 95.7 \\
\hline 2 & 49.6 & 50.0 & 96.4 & 93.6 \\
\hline 3 & 48.9 & 50.0 & 93.8 & 89.7 \\
\hline 4 & 53.1 & 50.0 & 101.5 & 96.8 \\
\hline 5 & 50.5 & 50.0 & 97.0 & 93.0 \\
\hline 6 & 51.8 & 50.0 & 98.9 & 94.2 \\
\hline $\begin{array}{l}\mathbb{X x} \pm \\
\mathrm{Sd}\end{array}$ & $51.0 \pm 1.5$ & $50.0 \pm 0.0$ & $97.9 \pm 2.5$ & $\begin{array}{l}93.8 \\
\pm 2.3\end{array}$ \\
\hline $\mathrm{cV} \%$ & 2.9 & 0.0 & 2.6 & 2.4 \\
\hline
\end{tabular}

\section{Resident Food Structure And Primary Food Intake}

In the pastoral area, the food structure is predominantly composed of meat, dairy, grain, and cereal foods. Meats primarily included yak beef, dried yak beef, and lamb, and no pork or poultry. Dairy foods primarily included yak milk, milk tea, and yogurt made from yak milk. In the agricultural area, the food structure primarily included grains, cereals, and vegetable food, with meats and dairy foods comprising a smaller portion of the diet. Meats primarily included cattle beef, dried cattle beef, lamb, and a small quantity of pork and chicken. Dairy products primarily included cattle milk and their products. The beef, mutton, cow milk, and goat milk consumed by residents of the agricultural and pastoral areas were primarily selfsupplied. The beef was mostly air-dried and transformed into dried beef for long-term preservation (approximately $2.35 \mathrm{~kg}$ of fresh beef is needed to generate $1 \mathrm{~kg}$ of dried beef). A small quantity of fresh beef was frozen for long-term preservation. Both areas had similar grain, cereal, and vegetable food varieties. Grain and cereal foods primarily included barley, wheat, and rice. The vegetables primarily included Chinese cabbage, radish, green pepper, and cucumber. The vegetables in the pastoral areas are primarily supplied by the agricultural areas. Both areas are inhabited by Tibetans, who do not have the habit of eating fish or seafood.

After food categorization, the daily intake of meats, dairy, cereals, vegetables, potatoes, and eggs per capita was compiled as shown in Table 5. The quantity of fresh beef was proportionately converted to the quantity of dried beef (Table 5). The intake of meat, dairy, and cereal foods was significantly higher in 
the pastoral areas than in the agricultural areas $(p<0.05)$. The potato consumption was higher in the agricultural areas than in the pastoral areas $(p<0.05)$. The consumption of vegetables and eggs was not significantly different between the two areas $(p>0.05)$. The daily food consumption of the residents of the pastoral and agricultural areas is shown in Figure 1 and Figure 2, respectively.

Table 5

\begin{tabular}{|c|c|c|c|c|c|c|}
\hline & \multicolumn{2}{|c|}{ Men } & \multicolumn{2}{|c|}{ Women } & \multicolumn{2}{|c|}{ Total } \\
\hline & $\mathrm{n}$ & Average age & $\mathrm{n}$ & Average age & $\mathrm{n}$ & Average age \\
\hline Pastoral area & 53 & $36.25 \pm 1.59$ & 47 & $36.74 \pm 1.58$ & 100 & $36.48 \pm 1.12$ \\
\hline agricultural area & 46 & $37.00 \pm 1.67$ & 54 & $38.50 \pm 1.40$ & 100 & $37.81 \pm 1.08$ \\
\hline $\mathrm{p}$ & & 0.745 & & 0.406 & & 0.393 \\
\hline
\end{tabular}

\section{Resident protein intake}

Protein intake was calculated by multiplying the food intake by the protein content in the foods. The protein content in foods (primarily meat, dairy, and cereals with a high protein content) was sourced from the Chinese Food Composition [25]. The calculated protein intake of residents is shown in Table 6. The per capita daily protein intake was $99.6 \mathrm{~g}$ in the pastoral area, which was higher than the intake of 80 $\mathrm{g} /$ day recommended by the Chinese Nutrition Society for an adult male who performs moderate physical labor [25]. In contrast, the protein intake was $56.5 \mathrm{~g}$ in the agricultural area, which was far lower than the recommended intake.

Table 6 Per capita daily intake of protein $(\mathrm{g})$ in the pastoral and agricultural areas

\begin{tabular}{|c|c|c|c|c|c|c|c|}
\hline & \multicolumn{3}{|c|}{ Pastoral residents' daily intake } & \multirow[t]{2}{*}{$\mathrm{p}$} & \multicolumn{3}{|c|}{ Agricultural residents' daily intake } \\
\hline & Median & Interquartile & Range & & Median & Interquartile & Range \\
\hline Meat protein & 53.2 & 38.0 & $0-212.8$ & 0.000 & 15.2 & 30.4 & $0-76.0$ \\
\hline Dairy protein & 8.0 & 8.8 & $0-25.3$ & 0.000 & 4.4 & 1.7 & $0-15.4$ \\
\hline $\begin{array}{l}\text { Cereal } \\
\text { protein }\end{array}$ & 41.8 & 12.2 & $11.7-69.0$ & 0.006 & 36.0 & 13.2 & $12.1-65.2$ \\
\hline Total & 99.6 & 43.1 & $\begin{array}{l}17.8- \\
293.3\end{array}$ & 0.000 & 56.5 & 27.3 & $\begin{array}{l}12.5- \\
140.3\end{array}$ \\
\hline
\end{tabular}




\section{Thyroid Hormone Levels In Meat And Milk}

Ninety-five dried yak beef samples and 100 yak milk samples were collected from families in the pastoral areas. In total, 75 dried cattle beef samples, 10 pork samples, and 100 cattle milk samples were collected from families in the agricultural areas. The investigation took place in the summer, and the residents seldom consumed mutton and sheep milk in the summer. Only one mutton sample was collected from an agricultural area. The test results for iodine and thyroid hormone levels in the meat and dairy foods are shown in Table 7. The results revealed that the levels of thyroid hormone were significantly (2.5 times) higher in the dried beef samples from the pastoral areas than those from the agricultural areas $(p<0.05)$. The level of thyroid hormone in cow milk was also significantly (3.3 times) higher in the pastoral areas than in the agricultural areas $(p<0.05)$. Such differences may primarily arise from the different species of cattle used in these areas. The pork samples from the agricultural areas contained almost no thyroid hormone.

Table 7

\begin{tabular}{|c|c|c|c|c|c|c|c|}
\hline & \multicolumn{3}{|c|}{ Pastoral residents' daily intake } & \multirow[t]{2}{*}{$\mathbf{p}$} & \multicolumn{3}{|c|}{ Agricultural residents' daily intake } \\
\hline & Median & Interquartile & Range & & Median & Interquartile & Range \\
\hline Meat protein & 53.2 & 38.0 & $0-212.8$ & 0.000 & 15.2 & 30.4 & $0-76.0$ \\
\hline Dairy protein & 8.0 & 8.8 & $0-25.3$ & 0.000 & 4.4 & 1.7 & $0-15.4$ \\
\hline $\begin{array}{l}\text { Cereal } \\
\text { protein }\end{array}$ & 41.8 & 12.2 & $11.7-69.0$ & 0.006 & 36.0 & 13.2 & $12.1-65.2$ \\
\hline Total & 99.6 & 43.1 & $\begin{array}{l}17.8- \\
293.3\end{array}$ & 0.000 & 56.5 & 27.3 & $\begin{array}{l}12.5- \\
140.3\end{array}$ \\
\hline
\end{tabular}

In order to observe the stability of the thyroid hormone in beef jerky, six samples with low, medium, and high levels of thyroid hormone were selected and assessed again after being stored at $4^{\circ} \mathrm{C}$ for 3 months. The average relative deviation between the two measurements was $5.4 \%$, which indicated that the thyroid hormone in beef jerky was stable, as shown in Table 8. 


\begin{tabular}{|c|c|c|c|c|c|c|c|}
\hline & \multicolumn{3}{|c|}{ Pastoral residents' daily intake } & \multirow[t]{2}{*}{$\mathbf{p}$} & \multicolumn{3}{|c|}{ Agricultural residents' daily intake } \\
\hline & Median & Interquartile & Range & & Median & Interquartile & Range \\
\hline Dried beef & 80.9 & 37.6 & $\begin{array}{l}11.6- \\
323.7\end{array}$ & 0.000 & 46.2 & 41.8 & $\begin{array}{l}8.9- \\
155.6\end{array}$ \\
\hline Mutton & 83.3 & 41.7 & $\begin{array}{l}33.3- \\
100.0\end{array}$ & 0.232 & 25.0 & 85.4 & $\begin{array}{l}16.7- \\
125.0\end{array}$ \\
\hline Pork & 16.7 & 16.7 & $0.0-33.3$ & 0.233 & 33.3 & 33.3 & $\begin{array}{l}8.3- \\
133.3\end{array}$ \\
\hline Meat total & 116.7 & 66.7 & $0.0-420.0$ & 0.000 & 50.0 & 47.9 & $\begin{array}{l}0.0- \\
166.7\end{array}$ \\
\hline Milk & 216.7 & 475.0 & $\begin{array}{l}0.0- \\
1250.0\end{array}$ & 0.000 & 72.2 & 202.1 & $\begin{array}{l}0.0- \\
1000.0\end{array}$ \\
\hline Eggs & 0.0 & 0.0 & $0.0-1.0$ & 0.614 & 0.0 & 0.0 & $0.0-1.33$ \\
\hline Barley & 100.0 & 50.0 & $\begin{array}{l}41.7- \\
266.7\end{array}$ & 0.649 & 133.3 & 85.4 & $\begin{array}{l}0.0- \\
416.7\end{array}$ \\
\hline Wheat & 183.3 & 91.7 & $\begin{array}{l}16.7- \\
366.7\end{array}$ & 0.222 & 166.7 & 83.3 & $\begin{array}{l}16.7- \\
400.0\end{array}$ \\
\hline Rice & 133.3 & 83.3 & $\begin{array}{l}33.3- \\
300.0\end{array}$ & 0.000 & 83.3 & 66.7 & $\begin{array}{l}8.3- \\
333.3\end{array}$ \\
\hline Cereal total & 433.3 & 125.0 & $150-700$ & 0.000 & 375.0 & 108.3 & $\begin{array}{l}150- \\
666.6\end{array}$ \\
\hline $\begin{array}{l}\text { Chin. } \\
\text { Cabbage }\end{array}$ & 50.0 & 33.3 & $\begin{array}{l}16.7- \\
150.0\end{array}$ & 0.009 & 66.7 & 50.0 & $\begin{array}{l}16.7- \\
183.3\end{array}$ \\
\hline Green pepper & 33.3 & 16.7 & $\begin{array}{l}16.7- \\
100.0\end{array}$ & 0.156 & 16.7 & 16.7 & $\begin{array}{l}16.7- \\
50.0\end{array}$ \\
\hline Tomato & 16.7 & 8.3 & 16.7-33.3 & 0.016 & 50.0 & 50.0 & $\begin{array}{l}33.3- \\
100.0\end{array}$ \\
\hline Cauliflower & 16.7 & 0.0 & $0.0-16.7$ & 0.022 & 33.3 & 12.5 & $\begin{array}{l}16.7- \\
50.0\end{array}$ \\
\hline Eggplant & 16.7 & 16.7 & 16.7-33.3 & - & 0.0 & 0.0 & 0.0 \\
\hline Lettuce & 33.3 & 16.7 & $\begin{array}{l}16.7- \\
100.0\end{array}$ & 0.072 & 33.3 & 16.7 & $\begin{array}{l}16.7- \\
66.7\end{array}$ \\
\hline Radish & 33.3 & 20.8 & 16.7-66.7 & 0.288 & 33.3 & 33.3 & $\begin{array}{l}16.7- \\
83.3\end{array}$ \\
\hline
\end{tabular}




\begin{tabular}{|c|c|c|c|c|c|c|c|}
\hline & \multicolumn{3}{|c|}{ Pastoral residents' daily intake } & \multirow[t]{2}{*}{$\mathbf{p}$} & \multicolumn{3}{|c|}{ Agricultural residents' daily intake } \\
\hline & Median & Interquartile & Range & & Median & Interquartile & Range \\
\hline Mushroom & 16.7 & 12.5 & 16.7-83.3 & 0.104 & 33.3 & 25.0 & $\begin{array}{l}16.7- \\
66.7\end{array}$ \\
\hline Pumpkin & 16.7 & 37.5 & $\begin{array}{l}16.7- \\
100.0\end{array}$ & 0.817 & 25.0 & 4.5 & $\begin{array}{l}16.7- \\
33.3\end{array}$ \\
\hline Cucumber & 16.7 & 16.7 & $16.7-66.7$ & 0.957 & 25.0 & 4.5 & $\begin{array}{l}16.7- \\
33.3\end{array}$ \\
\hline $\begin{array}{l}\text { Vegetable } \\
\text { total }\end{array}$ & 83.3 & 62.5 & $0-300$ & 0.155 & 83.3 & 66.7 & $0-250$ \\
\hline Potato & 50 & 83.3 & $0-216.6$ & 0.000 & 0.0 & 16.6 & $0-133.3$ \\
\hline
\end{tabular}

Six beef jerky samples were initially measured using the method recommended by the ATA for the determination of thyroid hormone in the tissues [18]. Although the reproducibility of the ATA method for measuring thyroid hormone in beef jerky was poor, there was a good correlation between the mean values measured using the ATA method and those measured using the organic iodine method. The content of thyroid hormone in beef jerky determined using the organic iodine method was higher than that determined using the ATA method, as shown in Table 9.

Table 9

\begin{tabular}{|llll|}
\hline $\begin{array}{l}\text { Sample } \\
\text { No. }\end{array}$ & $\begin{array}{l}\text { Thyroid hormone content } \\
\text { at first test }\end{array}$ & $\begin{array}{l}\text { Thyroid hormone content at } \\
\text { second test }\end{array}$ & $\begin{array}{l}\text { Relative deviation between } \\
\text { two tests (\%) }\end{array}$ \\
\hline NQ 073 & 11.01 & 9.56 & -13.2 \\
\hline NQ 084 & 14.04 & 12.68 & -9.7 \\
\hline NQ 081 & 61.26 & 60.25 & -1.6 \\
\hline NQ 058 & 65.11 & 59.84 & -8.1 \\
\hline NQ 018 & 171.4 & 167.8 & -2.1 \\
\hline NQ 032 & 215.3 & 220.1 & 2.2 \\
\hline Mean & - & - & -5.4 \\
\hline Comparison of the results obtained using the two methods $(\mu \mathrm{g} / \mathrm{kg})$ & \\
\hline
\end{tabular}


Intake of thyroid hormone from meat and dairy sources by the residents

The content of thyroid hormone in the meat and milk of each household was multiplied by the average amount of meat and milk consumed by each household member to obtain the per capita daily intake of the thyroid hormone, as shown in Table 10. The per capita daily intake of thyroid hormone was significantly (6 times) higher in the pastoral areas than in the agricultural areas $(p<0.05)$.

Table 10

\begin{tabular}{|llll|}
\hline $\begin{array}{l}\text { Sample } \\
\text { No. }\end{array}$ & $\begin{array}{l}\text { Thyroid hormone } \\
\text { determined using the ATA } \\
\text { method }(\mathbf{n}=\mathbf{6})\end{array}$ & $\begin{array}{l}\text { Thyroid hormone determined } \\
\text { using the organic iodine method } \\
(\mathbf{n}=\mathbf{6})\end{array}$ & $\begin{array}{l}\text { Relative deviation } \\
\text { between the two } \\
\text { methods }(\%)\end{array}$ \\
\hline CH 002 & $11.6 \pm 2.9$ & $18.7 \pm 0.75$ & -38.0 \\
\hline CH057 & $39.7 \pm 3.7$ & $49.3 \pm 1.5$ & -19.5 \\
\hline CH071 & $30.8 \pm 7.2$ & $37.0 \pm 1.1$ & -16.8 \\
\hline NQ 085 & $46.6 \pm 8.8$ & $57.7 \pm 2.2$ & -19.2 \\
\hline NQ 018 & $31.2 \pm 5.6$ & $39.4 \pm 1.7$ & -20.8 \\
\hline NQ 053 & $25.2 \pm 5.3$ & $27.8 \pm 1.4$ & -9.4 \\
\hline $\begin{array}{l}\text { Corr. } \\
\text { Coef. }\end{array}$ & -0.8445 & Mean RD\% & -20.6 \\
\hline Per capita daily intake $(\mu \mathrm{gg})$ of thyroid hormone from meat and dairy & \\
\hline
\end{tabular}

\section{Intake Of Selenium And Iron Microelements By The Residents}

Selenium and iron alleviate thyroid goiter [26-29]. To obtain the per capita daily intake of selenium and iron in the pastoral and agricultural areas, the residents' daily intake of various foods in the agricultural and pastoral areas was multiplied by the mean levels of selenium and iron in the foods. The mean levels of selenium and iron in the various foods were sourced from the "China Food Composition" (2004) [25]. Table 11 shows that the intake values of selenium and iron were both higher in the pastoral areas than in the agricultural areas, and this difference was statistically significant $(p<0.05)$. 


\begin{tabular}{|c|c|c|c|c|c|c|c|}
\hline \multirow[t]{2}{*}{$\begin{array}{l}\text { Source of thyroid } \\
\text { hormone }\end{array}$} & \multicolumn{4}{|c|}{$\begin{array}{l}\text { Pastoral residents' daily intake of } \\
\text { thyroid hormone }\end{array}$} & \multicolumn{3}{|c|}{$\begin{array}{l}\text { Agricultural residents' daily } \\
\text { intake of thyroid hormone }\end{array}$} \\
\hline & Median & Interquartile & Range & p & Median & Interquartile & Range \\
\hline Beef & 4.98 & 4.65 & $\begin{array}{l}0.86- \\
38.8\end{array}$ & 0.000 & 1.09 & 1.52 & $\begin{array}{l}0.02- \\
22.2\end{array}$ \\
\hline Milk & 3.74 & 7.80 & $\begin{array}{l}0.14- \\
40.6\end{array}$ & 0.000 & 0.93 & 4.14 & $\begin{array}{l}0.0- \\
74.3\end{array}$ \\
\hline Beef and milk & 9.62 & 10.8 & $\begin{array}{l}0.90- \\
47.2\end{array}$ & 0.000 & 1.54 & 2.95 & $\begin{array}{l}0.06- \\
75.3\end{array}$ \\
\hline mutton & 0.84 & - & - & - & 0.25 & & \\
\hline Total & 10.5 & & & & 1.79 & & \\
\hline
\end{tabular}

\section{Discussion}

\section{Effects of iodine, thyroid hormone, and protein on the thyroid function}

lodine has biological effects only when it contributes towards the synthesis of thyroid hormones within the body. However, not all iodine obtained from the diet can be utilized for thyroid hormone synthesis in the human body and some of it is excreted through the kidneys. In people who have a low protein intake, such as vegetarians, the bioavailability of iodine is limited [30-33]. The bioavailability of thyroid hormones is approximately $100 \%$, and almost all thyroid hormones absorbed from food can enter the bloodstream to directly perform their biological functions [34, 35]. As a result, consuming iodine in the form of thyroid hormone is more effective than taking inorganic iodine to compensate for the lack of thyroid hormone synthesis arising from iodine deficiency. The results of this survey show that the dietary intake of thyroid hormone of the residents in the pastoral areas was significantly higher than that in the agricultural areas, which may be the main reason for the significantly lower goiter rate of the residents in the pastoral areas, compared to that in the agricultural areas. The experimental results showed that the thyroid hormone in dried beef had good stability. Even if deiodinase is present in beef, it may be denatured and deactivated in dried beef or the enzymatic reaction may not occur under dry conditions. Clinically, the recommended dose of thyroxine for treating hypothyroidism was initially $35 \mu \mathrm{g}$ per day for children and $50 \mu \mathrm{g}$ per day for pregnant women with subclinical hypothyroidism [36, 37]. This treatment regimen was specifically designed for patients with hypothyroidism due to thyroid dysfunction. However, the residents in the pastoral areas were different from patients with thyroid dysfunction, with their thyroid 
glands being normally enriched in iodine to synthesize thyroid hormones. The thyroid hormone synthesized by the pastoral residents and the thyroid hormone ingested from meat and milk food (although it was only $10.5 \mu \mathrm{g}$ per day) could still maintain the normal levels of thyroid function, sparing them from the iodine deficiency disorders. Moreover, the relatively high intake of protein and trace elements selenium and iron by residents in the pastoral area, which effectively promotes the absorption and use of iodine in the body, could be another important factor for reducing the goiter rates.

Another survey in 2009 [10] found that the coverage rate of iodized salt (iodine content of $25 \mathrm{mg} / \mathrm{kg}$ ) in agricultural areas was $90 \%$, and that no resident in the pastoral areas consumed iodized salt. The median urinary iodine of the population in the pastoral areas $(50.2 \mu \mathrm{g} / \mathrm{L})$ was significantly lower than that in agricultural areas $(193.2 \mu \mathrm{g} / \mathrm{L}),(\mathrm{p}<0.01)$. The levels of $\mathrm{FT}_{4}$ and $\mathrm{TT}_{4}$ in women of childbearing age in the pastoral areas $(14.0 \pm 2.0 \mathrm{pmoL} / \mathrm{L}$ and $85.6 \pm 17.5 \mathrm{nmoL} / \mathrm{L}$, respectively) were significantly lower than those in women from the agricultural areas $(16.2 \pm 6.3 \mathrm{pmoL} / \mathrm{L}$ and $95.4 \pm 21.1 \mathrm{nmoL} / \mathrm{L}$, respectively) (p $<0.05)$. Nevertheless, the goiter rate in children and women of childbearing age in the pastoral areas $(1.0 \%)$ was significantly lower than that in the agricultural areas $(18.0 \%)(p<0.01)$. The rate of abnormal thyroid function in women of childbearing age in the pastoral areas $(5.9 \%)$ was significantly lower than that in the agricultural areas $(25.5 \%)(p<0.05)$. Moreover, the prevalence of subclinical hypothyroidism $(2.9 \%)$ was significantly lower in the pastoral areas than in the agricultural areas $(21.3 \%)(p<0.05)$. Teng $W$ et al. investigated the changes in thyroid diseases after the implementation of USI and found that the prevalence of subclinical hypothyroidism in China in 1999, 2011, and 2017 was 3.22, 16.7, and 13.7\%, respectively, and the goiter rate was $5.02,2.9$, and $1.8 \%$, respectively $[38,39]$. The prevalence of subclinical hypothyroidism in the Tibetan pastoral areas was significantly lower than the national level during the same period. The goiter rate is on par with the national level, which meets the elimination standard of iodine deficiency disorders (goiter rate lower than 5\%) [1]. These comparisons showed that the level of thyroid function among the residents of the pastoral areas of Tibet was normal. Since 2009, some pastoral residents have voluntarily chosen to use iodized salt, and their urine iodine level has increased to a certain extent, reaching $63 \mu \mathrm{g} / \mathrm{L}$ in 2011 [7]. Therefore, the pastoral areas should not be forced to implement the USI policy. An excess iodine intake may cause other thyroid diseases, such as goiter, hypothyroidism and autoimmune thyroiditis, which were confirmed by Teng $W$ et al. [38-41]. It is suggested that iodized salt and non-iodized salt should be allowed to coexist in pastoral markets for residents to choose from.

\section{Reasons for the elevated thyroid hormone levels in meat and yak milk from the pastoral areas}

The pastoral areas are at a high altitude (above 4,000 m), with very low temperatures and low amounts of oxygen. Herdsmen have lived on pasturage for generations, primarily by raising yaks. To adapt to the blistering cold environment, yaks may have developed an increased ability to store nutrients. The literature indicates that yak beef and milk have higher levels of minerals, proteins, and iodine than those from other types of bovines [42]. A report on the increased iodine levels in yak beef and milk compared to cattle beef and milk matches the conclusion of this study. The water iodine levels in the pastoral areas (median $1.3 \mu \mathrm{g} / \mathrm{L}$ ) are higher than those in the agricultural areas (median $0.7 \mu \mathrm{g} / \mathrm{L}$ ) [10], potentially 
promoting favorable conditions for yaks to gather and reserve iodine for the synthesis of thyroid hormone. In addition to the inborn quality of yaks in the pastoral areas, the slaughter via drowning instead of exsanguination and yak beef production through natural drying, rather than water washing, also increases the blood content in the muscles, contributing to the higher levels of thyroid hormone in dried yak beef.

\section{Conclusions}

The significantly high intake of the food-borne thyroid hormone by residents in the pastoral area, which effectively compensates for the lack of synthetic thyroid hormones arising from iodine deficiency in the human body, could be the main reason residents in the pastoral areas show a lower rate of thyroid goiter than those in the agricultural area. Moreover, the relatively high intake of protein and trace elements, selenium and iron by residents in the pastoral area, which effectively promotes the absorption and use of iodine in the body, could be another important factor for reducing the goiter rates. In combination with other studies, it can be estimated that the thyroid function of people in pastoral areas is normal. Therefore, the pastoral areas of Tibet should not be forced to implement a salt iodization policy, and iodized and non-iodized salt should coexist in the pastoral markets for residents to choose from.

\section{Declarations}

\section{Acknowledgements}

We thank the National Natural Science Foundation of China (grant number: 81072246 ) for funding this research. We also thank all the residents and their families in the pastoral and agricultural areas of Tibet for participating in the survey.

\section{Ethics approval and consent to participate}

The study was reviewed by the meeting of the ethics committee of the National Institute for Communicable Disease Control and Prevention, China CDC, and the ethical review approval number was ICDC-2014001. All participants signed an informed consent form.

\section{Conflict of Interest Statement}

The authors have no conflicts of interest to declare.

\section{Funding Sources}

This work was funded by the National Natural Science Foundation of China (grant number: 81072246).

\section{Author Contributions}


The authors' responsibilities were as follows: J. Xu and SC. Liu designed the research and wrote the first draft of the manuscript; W. Ma, XW. Li and XX. Cao improved the method for measuring thyroid hormone in dried beef and carried out the determination of the thyroid hormone levels in meat and milk; M. Guo participated in the dietary survey and served as a Tibetan interpreter; YY. Gu, JQ. Wang, HY, Wang, and GX, Zhuang organized and participated in the field investigation; Y. Zhang performed the statistical analysis of the data; LJ. Liu improved the research design, directed the on-site dietary investigations, and had the primary responsibility of the final content; all authors contributed to writing and editing the manuscript.

\section{Data Availability Statement}

The data described in the manuscript, code book, and analytic code will be made available upon request.

\section{References}

1. WHO, UNICEF, ICCIDD. Assessment of iodine deficiency disorders and monitoring their elimination: a guide for program managers. 3rd ed. Geneva, Switzerland: World Health Organization; 2007.

2. Chen ZP. Progress of IDD elimination in China. J. Prev. Med Inf. 2000; 16: 93-94 (in Chinese).

3. Li S, Wei H, Zheng Q. Elimination of iodine-deficiency disorders in Tibet. Lancet. 2008; 371: 1980-1.

4. Xirao RD, Danzeng SB, Nima ZD. The status of iodine deficiency disorders in Tibet. Tibet Medicine. 1996;17: 40-4 (in Chinese).

5. The State Council of the People's Republic of China. The management regulations for salt iodization to eliminate iodine deficiency hazard. 2011. http://www.gov.cn/banshi/200508/01/content_19114.htm (in Chinese).

6. Danzeng SB, Xirao RD, Luosang DJ, Guo M, Pu Q. Analysis of IDD surveillance in Tibet autonomy region in 2002. Chin J Endemiol. 2003; 22: 344-346. (in Chinese.)

7. Sun DJ, Xiao DL, Liu SJ. The survey of iodine deficiency disorders in China in 2011. Beijing: People's Health Publishing House; 2014.

8. Du Dan, Li Sumei, Li Xiuwei, Wang Haiyan, Li Shuhua, Nima Cangjue, Danzeng Sangbu, Zhuang Guangxiu. Study on the iodine nutrition and iodine deficiency disorders status in pasturing areas of Tibet -a non-epidemic area of iodine deficiency disorders in serious iodine deficiency district. Chinese J Epidemiology. 2010; 31: 863-865.

9. Du Dan, Li Sumei, Li Xiuwei, Wang Haiyan, Li Shuhua, Nima Cangjue, Danzeng Sangbu, Zhuang Guangxiu. A dietary survey on iodine and other nutrients in pastoral areas of Tibet. Chinese $\mathrm{J}$ Control Endemic Diseases. 2011; 26: 168-171.

10. Du Dan, Li Jiantao, Li Sumei, Li Xiuwei, Wang Haiyan. Analysis of iodine nutrition of people and serum thyroid hormone levels of women of childbearing age in pasturing areas of Tibet in 2009. Chin J Endemiol. 2011; 30: 535-538.

11. Duojizhandu, Wu Huajian. Tibet statistical yearbook 2017. Beijing: China Statistics Press; 2017.

12. Sun ZQ, Xu YY. Medical statistics. 4th edit. Beijing: People's Health Publishing House; 2018. 
13. Anwar T Merchant, Mahshid Dehghan, Jephat Chifamba, Getrude Terera, Salim Yusuf. Nutrient estimation from an FFQ developed for a black Zimbabwean population. Nutrition Journal. 2005; 4: 37.

14. Mirmiran P, Esfahani FH, Mehrabi Y, Hedayati M, Azizi F. Reliability and relative validity of an FFQ for nutrients in the Tehran Lipid and Glucose Study. Public Health Nutrition. 2009; 13: 654-662.

15. Elizabeth Barreti-Connor. Nutrition epidemiology: how do we know what they ate? Am J Clin Nutr. 199|; 54: 182S-187S.

16. Wu xinyun, Wang zhixu, Ma xiuling, Wu jieshu, Fan ping, Li zhuwen. The evaluation study on accuracy of $24 \mathrm{~h}$ dietary recall method assisted with illustrative food pictures, Acta Nutrimenta Sinica. 2012; 34: 558-562.

17. Zhang Qian, Lian Xiaolan, Chai Xiaofeng, Bai Yao, Dai Weixin. Relationship between maternal milk and serum Thyroid hormones in Patients with Thyroid Related Diseases. Acta academiae medicinae sinicae. 2013; 35: 427-431.

18. American Thyroid Association. American thyroid association guide to investigating thyroid hormone economy and action in rodent and cell models. Thyroid. 2014; 24: 100-101.

19. Reviczky AL, Szántó L. Correlation between the thyroxine-binding capacity of blood proteins and the serum organic iodine level. Acta Physiol Acad Sci Hung. 1967; 32: 337-348.

20. Farran HE, Haiste C, Hoffenberg R. A comparison of serum PBI and thyroxine iodine levels. Acta Endocrinologica. 1971; 68: 451-457.

21. Clark F. Serum protein-bound iodine or total thyroxine. J Clin Pathol. 1975; 28: 211-217.

22. Taurog, Chaikoff. On the nature of plasma iodine. 2011. http://jcem.endojournals.org/content/10/9/996.

23. Liejun Liu, Xiuwei Li, Haiyan Wang, Xiaoxiao Cao, Wei Ma. Reduction of iodate in iodated salt to iodide during cooking with iodine as measured by an improved HPLC/ICP-MS method. Journal of Nutritional Biochemistry. 2017; 42: 95-100.

24. The ministry of public health of P.R.C. Method for determination of iodine in foodstuff by As (III)Ce4+ catalytic spectrophotometry. Beijing: People's Health Press; 2008.

25. Yang YX. Chinese food composition. Beijing: Peking University Medical Press; 2004.

26. Eftekhari MH, Keshavarz SA, Jalali M, Elguero E, Eshraghian MR, Simondon KB. The relationship between iron status and thyroid hormone concentration in iron-deficient adolescent Iranian girls. Asia Pac J Clin Nutr. 2006; 15: 50-55.

27. Dabbaghmanesh MH, Sadegholvaad A, Ejtehadi F, Ranjbar-Omrani G. The role of iron deficiency in persistent goiter. Arch Iran Med. 2008; 11: 157-161.

28. Eftekhari MH, Simondon KB, Jalali. Effects of administration of iron, iodine and simultaneous ironplus-iodine on the thyroid hormone profile in iron-deficient adolescent Iranian girls. European Journal of Clinical Nutrition. 2006; 60: 545-552. 
29. Contempre B, Dumont JE, Bebe N, Thilly CH, Diplock AT, Vanderpas J. Effect of selenium supplementation in hypothyroid subjects of an iodine and selenium deficient area: the possible danger of indiscriminate supplementation of iodine-deficient subjects with selenium. J Clin Endocrinol Metab. 1991; 73: 213-215.

30. Ingenbleek Y, Beckers C. Evidence for intestinal malabsorption of iodine in protein-calorie malnutrition. Am J Clin Nutr. 1973; 26:1323-30.

31. Serena Tonstad, Edward Nathan, Keiji Oda, Gary Fraser. Vegan diets and hypothyroidism. Nutrients. 2013; 5: 4642-52.

32. Müller P. Vegan Diet in Young Children. Nestle Nutr Inst Workshop Ser. 2020; 93:103-110.

33. Groufh-Jacobsen S, Hess SY, Aakre I, Folven Gjengedal EL, Blandhoel Pettersen K, Henjum S. Vegans, vegetarians and pescatarians are at risk of iodine deficiency in Norway. Nutrients, 2020; 12:3555.

34. Boehler J. Oral thyroxine. Annals of Internal Medicine 1984; 101: 572-573.

35. Lisa H. Fish, Harold L. Schwartz, John Cavanaugh, Michael W. Steffes, John P. Bantle, Jack H. Oppenheimer. Replacement dose metabolism and bioavailability of Levothyroxine in the treatment of hypothyroidism. N Engl J Med. 1987; 316: 764-770.

36. Iraj Rezvaniab, Angelo M. DiGeorgeab. Reassessment of the daily dose of oral thyroxine for replacement therapy in hypothyroid children. The Journal of Pediatrics. 1977; 90: 291-297.

37. Inés Seoane Cruz, Manuel Penín Álvarez, Reyes Luna Cano, Ricardo Víctor García-Mayor. Treatment with fixed thyroxine doses in pregnant women with subclinical hypothyroidism. Endocrinología y Nutrición (English Edition). 2012; 59: 284-287.

38. Shan Z, Chen L, Lian X, Liu C, Shi B, Shi L, Tong N, Wang S, Weng J, Zhao J, Teng X, Yu X, Lai Y, Wang W, Li C, Mao J, Li Y, Fan C, Teng W. lodine status and prevalence of thyroid disorders after introduction of mandatory universal salt iodization for 16 years in China: a cross-sectional study in 10 cities. Thyroid. 2016, 26: 1125-30.

39. Wang C, Li Y, Teng D, Shi X, Ba J, Chen B, Du J, He L, Lai X, Li Y, Chi H, Liao E, Liu C, Liu L, Qin G, Qin Y, Quan H, Shi B, Sun H, Tang X, Tong N, Wang G, Zhang JA, Wang Y, Xue Y, Yan L, Yang J, Yang L, Yao Y, Ye Z, Zhang Q, Zhang L, Zhu J, Zhu M, Shan Z, Teng W. Hyperthyroidism prevalence in China after universal salt iodization. Front Endocrinol (Lausanne). 2021; 12: 651-5.

40. Teng W, Shan Z, Teng X, Guan H, Li Y, Teng D, Jin Y, Yu X, Fan C, Chong W, Yang F, Dai H, Yu Y, Li J, Chen Y, Zhao D, Shi X, Hu F, Mao J, Gu X, Yang R, Tong Y, Wang W, Gao T, Li C. Effect of iodine intake on thyroid diseases in China. N Engl J Med. 2006; 354: 2783-93.

41. Xu, T., Ren, Z., Li, S. et al. The relationship of different levels of high iodine and goiter in school children: a meta-analysis. Nutr Metab (Lond). 2021. https://doi.org/10.1186/s12986-021-00563-2

42. Wu H, Hang YY, Chen LH. Analysis on butterfat and iodine value in the milk of yaks and cattle-yak. Journal of Southwest Nationalities College - Natural Science Edition. 1998; 24: 61-63.

\section{Figures}




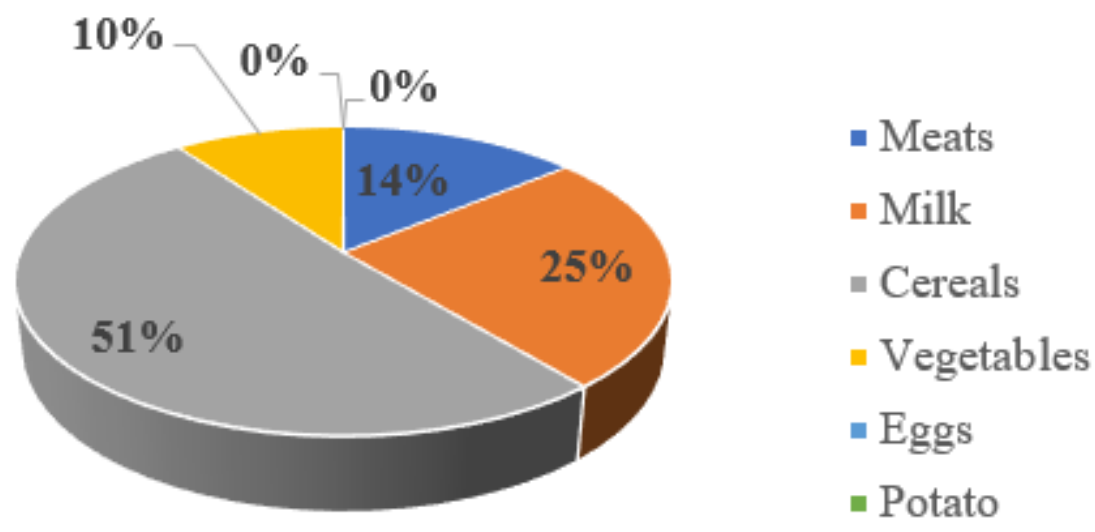

\section{Figure 1}

The daily food composition of residents in pastoral areas

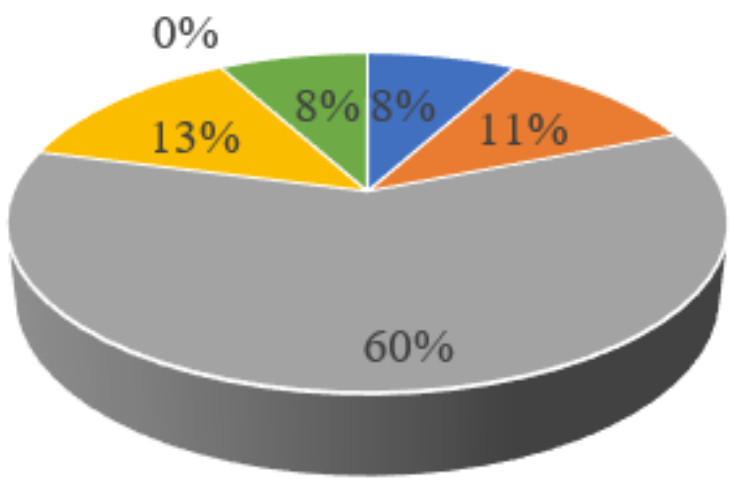
- Meats
- Milk
- Cereals
- Vegetables
- Eggs
- Potato

Figure 2

The daily food composition of residents in agriculture areas 